\title{
DDIT4 wt Allele
}

National Cancer Institute

\section{Source}

National Cancer Institute. DDIT4 wt Allele. NCI Thesaurus. Code C104185.

Human DDIT 4 wild-type allele is located in the vicinity of $10 \mathrm{q} 22.1$ and is approximately 2 $\mathrm{kb}$ in length. This allele, which encodes DNA damage-inducible transcript 4 protein, plays a role in responses to cellular stress and regulates apoptosis in response to DNA damage. 